\title{
Correction: A glycine zipper motif mediates the formation of toxic beta-amyloid oligomers in vitro and in vivo
}

\author{
Virginia Fonte ${ }^{1}$, Vishantie Dostal ${ }^{1}$, Christine M Roberts ${ }^{1}$, Patrick Gonzales ${ }^{1}$, Pascale N Lacor ${ }^{2}$, Pauline T Velasco ${ }^{2}$, \\ Jordi Magrane ${ }^{3}$, Natalie Dingwell ${ }^{4}$, Emily Y Fan ${ }^{4}$, Michael A Silverman ${ }^{4}$, Gretchen H Stein ${ }^{5}$ and \\ Christopher D Link ${ }^{1,6^{*}}$
}

\section{Correction}

After publication of this work [1], we noted that we inadvertently failed to include the complete list of all coauthors. The full list of authors has now been added and the Authors' contributions section has been modified accordingly.

\section{Authors' contributions}

C. elegans experiments were performed by VF, VD, CMR, PG, and CDL. Neuro 2a experiments were performed by GHS. Characterization of ADDL preps was performed by PTV. ADDL-binding and toxicity assays in hippocampal cultures were performed and analyzed by PNL, and Tau phosphorylation analysis done by ND, EYF and MAS. Adenovirus transfection of cortical neurons was performed by JM. GHS, PNL, MAS, JM and CDL prepared the manuscript. All authors have read and approved the final manuscript.

\begin{abstract}
Acknowledgements
The authors would like to thank Hilary Devlin for assistance with media preparation. Some nematode strains were provided by the Caenorhabditis Genetics Center, funded by the NIH National Center for Research Resources. This work was supported by an Alzheimer's Association Zenith Award (C.D.L), $\mathrm{NIH}$ award AG12423 (C.D.L), and Canadian Institutes for Health Research, Grant \# 102686 (M.A.S.). PNL and PTV were supported by funding granted to William Klein (Alzheimer's Association IIRG-06-26989; NIH award R01AG022547; AHAF \# A2006-092 and gift from Acumen Pharmaceuticals Inc).
\end{abstract}

\begin{abstract}
Author details
'Institute for Behavioral Genetics, University of Colorado, Boulder, CO 80309, USA. ${ }^{2}$ Department of Neurobiology and Physiology, Northwestern University, Evanston, IL 60208, USA. ${ }^{3}$ Department of Neurology and Neuroscience, Weill Medical College of Cornell University, New York, NY 10065, USA.

${ }^{4}$ Department of Biological Sciences, Simon Fraser University, Burnaby, BC V5A 1S6, Canada. ${ }^{5}$ Department of Molecular, Cellular and Developmental Biology, University of Colorado, Boulder, CO 80309, USA. 'Integrative Physiology, University of Colorado, Boulder, CO 80309, USA.
\end{abstract}

Received: 25 February 2014 Accepted: 25 February 2014 Published: 25 March 2014

\footnotetext{
*Correspondence: linkc@colorado.edu

'Institute for Behavioral Genetics, University of Colorado, Boulder, CO 80309, USA

${ }^{6}$ Integrative Physiology, University of Colorado, Boulder, CO 80309, USA Full list of author information is available at the end of the article
}

\section{Reference}

1. Fonte V, Dostal V, Roberts CM, Gonzales P, Lacor P, Magrane J, Dingwell N, Fan EY, Silverman MA, Stein GH, Link CD: A glycine zipper motif mediates the formation of toxic $\beta$-amyloid oligomers in vitro and in vivo. $\mathrm{Mol}$ Neurodegener 2011, 6:61.

\section{doi:10.1186/1750-1326-9-12}

Cite this article as: Fonte et al:: Correction: A glycine zipper motif mediates the formation of toxic beta-amyloid oligomers in vitro and in vivo. Molecular Neurodegeneration 2014 9:12.

\section{Submit your next manuscript to BioMed Central and take full advantage of: \\ - Convenient online submission \\ - Thorough peer review \\ - No space constraints or color figure charges \\ - Immediate publication on acceptance \\ - Inclusion in PubMed, CAS, Scopus and Google Scholar \\ - Research which is freely available for redistribution

